\title{
Philosophy of education courses' potential as main component in teacher-education program
}

\author{
Roni Reingold \\ Achva Academic College
}

\begin{abstract}
Nowadays, teacher-education programs tend to focus on the development of skills such as classroom management and lesson planning, as well as on theoretical and practical knowledge. The status of courses on the philosophy of education, which were considered essential during several decades of the last century, have become marginalized, at best. The current study aims to underscore the potential and practical contribution of these courses to the development of upstanding educators, by giving voice to the opinions of educators who participated in a unique teacher-education program in Israel, in which three courses on the philosophy of education played a pivotal role. The responses of the educators (all of whom are accredited in-service teachers with a Master's in Teaching) may be categorized as expressions of gratitude, either for the valuable and pleasant experience and/or for the tools and resources that help them become better teachers. Most frequently, responses referred to the program's contribution to their ability to think critically and develop moral courage.
\end{abstract}

Keywords: moral education; multicultural education; philosophy of education; teacher education; value education 